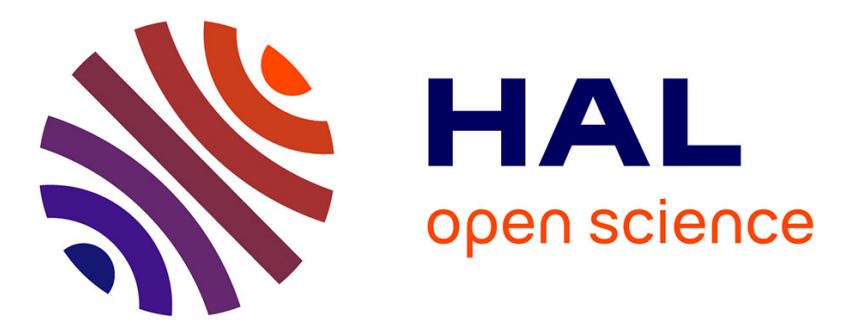

\title{
Dimethylsulfide, aerosols, and condensation nuclei over the tropical northeastern Atlantic Ocean
}

\author{
J.-P. Putaud, S. Belviso, B. Nguyen, N. Mihalopoulos
}

\section{To cite this version:}

J.-P. Putaud, S. Belviso, B. Nguyen, N. Mihalopoulos. Dimethylsulfide, aerosols, and condensation nuclei over the tropical northeastern Atlantic Ocean. Journal of Geophysical Research, 1993, 98 (D8), pp.14863. 10.1029/93JD00816 . hal-03585084

\section{HAL Id: hal-03585084 \\ https://hal.science/hal-03585084}

Submitted on 22 Feb 2022

HAL is a multi-disciplinary open access archive for the deposit and dissemination of scientific research documents, whether they are published or not. The documents may come from teaching and research institutions in France or abroad, or from public or private research centers.
L'archive ouverte pluridisciplinaire HAL, est destinée au dépôt et à la diffusion de documents scientifiques de niveau recherche, publiés ou non, émanant des établissements d'enseignement et de recherche français ou étrangers, des laboratoires publics ou privés. 


\title{
Dimethylsulfide, Aerosols, and Condensation Nuclei Over the Tropical Northeastern Atlantic Ocean
}

\author{
J.-P. PUTAUD, S. BELVISO, B. C. NGUYEN, and N. MIHALOPOULOS \\ Centre des Faibles Radioactivités, Laboratoire Mixte CNRS-CEA, Gif-sur-Yvette, France
}

\begin{abstract}
Concentration of dimethylsulfide (DMS) in seawater, concentrations of DMS and sulfur dioxide $\left(\mathrm{SO}_{2}\right)$ in the almosphere, concentrations of methanesulfonate (MSA) and non-sea-salt sulfate (nss- $\mathrm{SO}_{4}{ }^{2-}$ ) in sizesegregated aerosols, and number concentration of condensation nuclei $(\mathrm{CN})$ were measured during September and October 1991 in the northern tropical Allantic Ocean in order to assess the role of DMS in CN production over this oceanic area. Radon-222 activity and aerosol ionic composition were used to distinguish air masses with oceanic, continental, and/or polluted characters. No obvious covariation appeared between DMS and its oxidation products $\left(\mathrm{SO}_{2}, \mathrm{H}_{2} \mathrm{SO}_{4}\right.$, and $\left.\mathrm{MSA}\right)$ over the whole period of the experiment. However, the division of data into subsets according to continental tracer information allowed us to show that $\mathrm{SO}_{2}$ and nss- $\mathrm{SO}_{4}$ concentrations correlated with DMS concentration in unpolluted air masses. MSA and nss- $\mathrm{SO}_{4}{ }^{2-}$ were found to be mainly concentrated in particles with diameters $<$ of $0.6 \mu \mathrm{m}$. Daly mean nss- $\mathrm{SO}_{4}{ }^{2-}$ in the $<0.6-\mu \mathrm{m}$-diameter range and $\mathrm{CN}$ concentration were correlated $(R=0.91, n$ $=17, \mathrm{P}<0.001$ ), which suggests that $\mathrm{H}_{2} \mathrm{SO}_{4}$ is an important $\mathrm{CN}$ precursor. Atmospheric DMS and $\mathrm{CN}$ number daily mean concentrations also correlated $(R=0.82, n=21, \mathrm{P}<0.001)$. However, the CN population was strongly influenced by continental inputs less than $500 \mathrm{~km}$ downwind of Africa, whereas DMS seemed to be able to affect the $\mathrm{CN}$ number concentration at about $1500 \mathrm{~km}$ from this continent.
\end{abstract}

\section{INTRODUCTION}

It has been recognized that tropospheric submicrometer aerosol particles can affect the Earth's radiative budget either through a direct effect of backscattering the incident solar radiation [Charlson et al., 1990] or through their role as precursors of cloud condensation nuclei (CCN) [Charlson et al., 1992; Wigley, 1989], the number concentration of which influences cloud albedo [Coakley et al., 1987; Radke et al., 1989; Leiatch et al., 1992]. Sulfate appears to be the main compound in tropospheric aerosols, both over continental areas [Charlson et al., 1978], where it is produced after atmospheric oxidation of anthropogenic and/or volcanic sulfur dioxide $\left(\mathrm{SO}_{2}\right)$, and over the oceans [Twomey, 1971], where it is derived from dimethylsulfide (DMS), the major marine volatile sulfur compound [Cline and Bates, 1983; Andreae, 1986]. DMS is produced in seawater through biological and chemical processes that lead to the cleavage of dimethylsulfoniopropionate (DMSP), which is synthesized in the cells of various phytoplankton species [Dacey and Wakeham, 1986; Nguyen et al., 1988; Keller et al., 1989; Belviso et al., 1990]. A small fraction of this DMS is emitted to the atmosphere [Kiene and Bates, 1990], where laboratory and field experiments have shown it to be oxidized by radicals such as $\mathrm{OH}$ or $\mathrm{NO}_{3}$ to give mainly methanesulfonic acid (MSA), sulfur dioxide. $\left(\mathrm{SO}_{2}\right)$, and sulfuric acid $\left(\mathrm{H}_{2} \mathrm{SO}_{4}\right)$ [Yin et al., 1990; Barnes et al., 1991; Nguyen et al., 1992]. Globally, the marine source of sulfur is estimated to be twice the volcanic source but about 5 times smaller than the anthropic source [Bates et al., 1992a]. One can therefore wonder if the process involving oceanic DMS emission, its particulate oxidation products, and their effect on the Earth's albedo [Charlson et al., 1987; Legrand et al., 1988] is relevant for climate control.

Copyright 1993 by the American Geophysical Union.

Paper number 93JD00816.

0148-0227/93/93JB-00816\$05.00
However, DMS emissions are still thought to be the predominant source of sulfur over large oceanic provinces, especially in the southern hemisphere [Bates et al., 1992a], and the comparison between data obtained by Ayers et al. [1991] and Gras [1990] at Cape Grim. Tasmania, shows that atmospheric DMS and CCN concentrations present similar seasonal variations. In the northern hemisphere, the extent of the oceanic areas where the condensation nucleus (CN) population is not totally dominated by continental and/or anthropogenic aerosol but where biogenic DMS could play a distinguishable role as a $\mathrm{CN}$ precursor is still unknown. Very few works have reported variations in DMS flux and/or atmospheric concentrations with $\mathrm{CN}$ or $\mathrm{CCN}$ number concentration in the northern hemisphere. To our knowledge, only Hegg et al. [1991] measured DMS and size-segregated CCN over the northeastern Pacific Ocean and suggested a possible nonlinear relationship between these two parameters.

In this work, we report simultaneous measurements of the concentrations of DMS in seawater, DMS and $\mathrm{SO}_{2}$ in the atmosphere, MSA and non-sea-salt sulfate (nss- $\mathrm{SO}_{4}{ }^{2-}$ ) in sizesegregated aerosols, and $\mathrm{CN}$ number concentration obtained during an oceanic cruise in the tropical northeastern Atlantic Ocean. Concentration of ions, including $\mathrm{NO}_{3}^{-}, \mathrm{Na}^{+}, \mathrm{K}^{+}$, and $\mathrm{Ca}^{2+}$, were also measured in some of the samples to document the origins of aerosols. Radon- 222 activity was used as a tracer of continental air masses. Variations of these parameters are compared in order to discuss the influence of different sources on the $\mathrm{CN}$ population over this oceanic area.

\section{EXPERIMENTAL PROCEDURE}

Seawater and air samples were collected on board RV $L$ 'Atalante along the track of the oceanographic cruise EUMELI 3 during September 17-28 and October 5-22, 1991. The area investigated was between the Canary Islands $\left(27^{\circ} 45^{\prime} \mathrm{N}, 18^{\circ} 02^{\prime} \mathrm{W}\right)$, station $M\left(18^{\circ} 29^{\prime} \mathrm{N}, 21^{\circ} 05^{\prime} \mathrm{W}\right)$, and station $\mathrm{O}\left(21^{\circ} 02^{\prime} \mathrm{N}, 31^{\circ} 08^{\prime} \mathrm{W}\right)$, as depicted in Figure 1.

About 60 to $180 \mathrm{~mL}$ of surface seawater was sampled every 

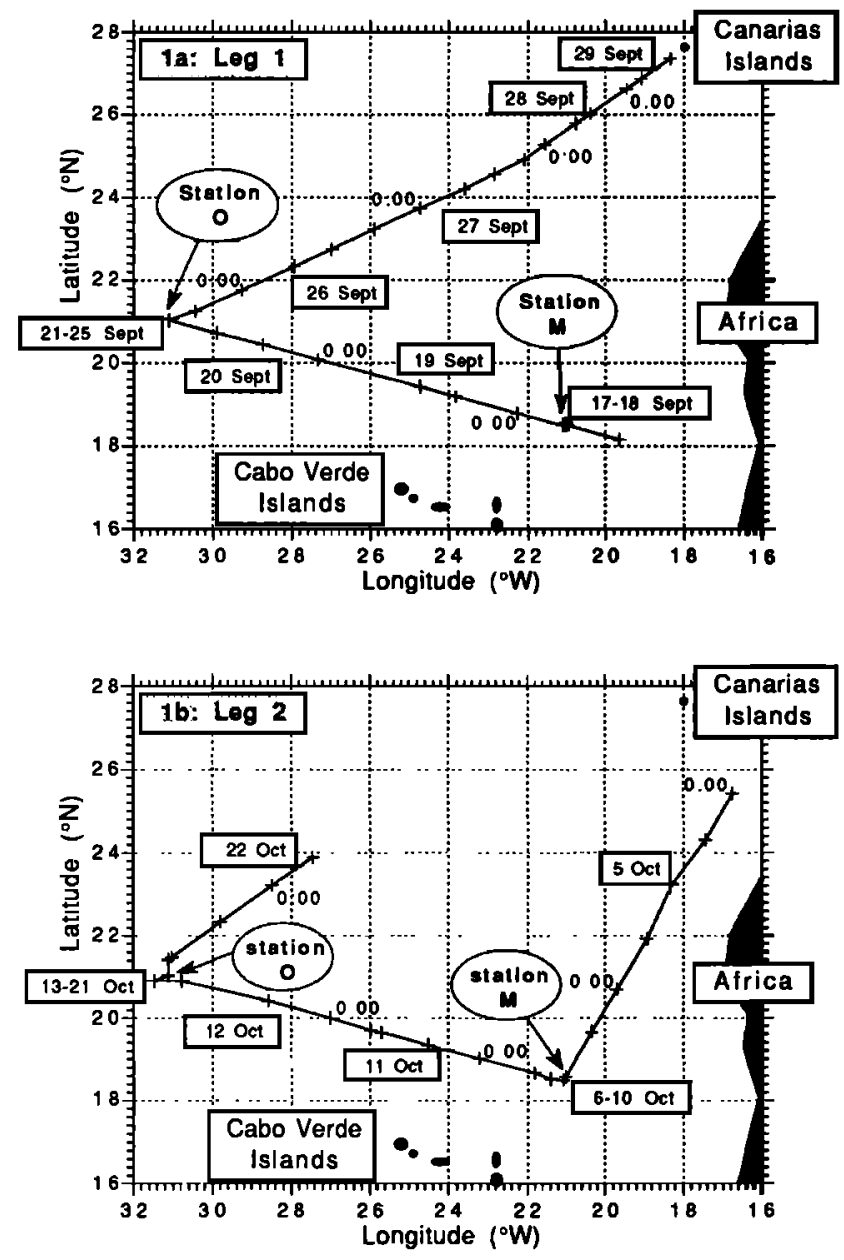

Fig. 1. Study area showing the ship track during the cruise EUMELI 3. Crosses represent DMS sampling sites.

6 hours, generally from the ship's seawater pumping system, the inlet of which is situated at the bow $5 \mathrm{~m}$ below sea level. DMS was extracted from seawater by helium bubbling at a flow rate of $100 \mathrm{~mL} / \mathrm{min}$ and concentrated in a cryogenic trap at $90^{\circ} \mathrm{C}$ before being analyzed by gas chromatography / flame photometric detection [Nguyen et al., 1990]. The precision of the analysis is estimated to be about $10 \%$. At stations, some seawater samples were collected at a 5-m depth with a Niskin bottle on a rosette sampler attached to a conductivity / temperature / depth system. The comparison between seven pairs of samples collected simultaneously from the non toxic supply of the boat and a Niskin bottle shows a DMS ratio of $0.96 \pm 0.15$, which indicates no significant difference in DMS concentration in the two sampling methods.

Atmospheric samples were collected from the top of the bow mast of the ship $16 \mathrm{~m}$ above sea level. For atmospheric DMS analysis, about 40-60 L of air was collected every 6 hours by compression in electropolished canisters with a noncontaminating pump. The analysis was performed within 1.5 hour by using the same method as for seawater [Nguyen et al., 1990]. The detection limit was about $0.8 \mathrm{nmol} \mathrm{m}^{-3}$ for this experiment.

$\mathrm{SO}_{2}$ and aerosols were sampled over 24-hour periods, starting at sunrise (about 08.00 local time). $A$ wind vane and an anemometer controlled the $\mathrm{SO}_{2}$ and aerosol pumps in order to sample only when the relative wind was forward of the ship's beam $\left( \pm 50^{\circ}\right)$ and moving faster than $1 \mathrm{~m} \mathrm{~s}^{-1} . \mathrm{SO}_{2}$ was collected by the West-Gaeke method [Nguyen et al., 1974], and the samples were stored at $+4^{\circ} \mathrm{C}$ until their analysis (addition of reagents and spectrophotometric measurement) in our laboratory less than 2 months after sampling. The detection limit of the method is $0.1-0.2 \mathrm{nmol} \mathrm{m}^{-3}$ for $3-$ to 5 $\mathrm{m}^{3}$ air samples. Aerosols were collected by using a six-stage cascade impactor (Sierra) at a flow rate of $70 \mathrm{~m}^{3} \mathrm{~h}$. Impaction substrates and final filters were made of Whatman-41 filter paper previously washed in $0.1 M \mathrm{HNO}_{3}$, rinsed 3 times in deionized water $(R=18.2 \mathrm{M} \mathrm{ohm})$, and stored in sealed plastic bags before and after sampling to be transported between the ship and the laboratory. The cutoff diameters were 9.8, 4.2, $2.5,1.2$, and $0.6 \mu \mathrm{m}$ for stages 1 through 5 , respectively. For the last stage (stage 6), the final filter was made of Whatman41 paper, whose efficiency for trapping particles in the radius range $0.01-0.2 \mu \mathrm{m}$ has been shown to be better than $80 \%$ under a high-volume regime (see for example Watts et al. [1987]). One quarter of each filter or substrate was extracted in $20 \mathrm{~mL}$ of deionized water in crystal polystyrene disposable Accuvette sample containers with ultrasonic agitation. Analysis was performed by ionic chromatography using a Dionex AS4A column for $\mathrm{HCOO}^{-}, \mathrm{CH}_{3} \mathrm{COO}^{-}, \mathrm{MSA}, \mathrm{NO}_{3}^{-}$, and $\mathrm{SO}_{4}{ }^{2-}$ and a CS 10 column for $\mathrm{Na}^{+}, \mathrm{K}^{+}$, and $\mathrm{Ca}^{2+}$ Our detection limit corresponded to concentrations below $2 \mathrm{pmol} \mathrm{m}^{-3}$.

The number concentration of $\mathrm{CN}$ was measured in real time with a TSI 3022 condensation particle counter (CPC) designed to detect nearly $100 \%$ of particles greater than $0.02 \mu \mathrm{m}$ in diameter with a gradual drop-off in detection efficiency below this size. It was positioned at the top of the bow mast and connected to a very short inlet rube $(30 \mathrm{~cm})$ to limit impaction of particles within the tube. However, the CPC absorbed a lot of sea-spray and had to be cleaned periodically with dry air for at least 24 hours. Furthermore, for technical reasons, the CPC was not connected to the wind vane, and to avoid any contamination of the nucleation cell, it was switched off when the ship was going into the wind. Our recording of $\mathrm{CN}$ concentration was therefore not continuous.

Radon-222, a tracer commonly used to document the transport of continental air masses, was sampled over 2-hour periods, and its activity was measured by following a method already described by Polian et al. [1986].

\section{RESULTS AND DISCUSSION}

\section{Meteorological Conditions and Air Mass Characterization}

Figure 1 indicates the ship track, the location of the Canary Islands, and the position of stations $M$ and $O$. Sea surface temperature (SST) was generally close to $26^{\circ} \mathrm{C}$ except around the Canaries and during our second visit to station $\mathrm{M}$ (October 6-10) when it was significantly lower than during our first visit to this site on September $17-18\left(25.2 \pm 0.2^{\circ} \mathrm{C}\right.$ versus $26.0 \pm 0.1^{\circ} \mathrm{C}$; Figure $2 a$ ). Wind speed varied between 1 and 14 m.s $\mathrm{s}^{-1}$ (mean, $7.1 \mathrm{~m} . \mathrm{s}^{-1}$ ) and was on average higher at station $M$ than at station $\mathrm{O}$ (Figure $2 b$ ). Except during the October 1315 and 18-20 periods, northeastern to eastern trade winds occurred (Figure $2 c$ ), so that sampling points were downwind of the African continent most of the time.

However, four periods can be distiguished by the daily mean ${ }^{222} \mathrm{Rn}$ activities, since they were above 7 and $10 \mathrm{pCi} \mathrm{m}^{-3}$ for September 17-20 and October 5-10, respectively, and below 4 and $3 \mathrm{pCi} \mathrm{m}^{-3}$ for September 21-29 and October 11-22, respectively (Figure $2 d$ ). During the last two periods, ${ }^{222} \mathrm{Rn}$ activity was close to that of the oceanic background. Air masses will therefore be considered as representative of oceanic conditions. It should be noted that this situation was always observed at station $O$, which is $1500 \mathrm{~km}$ downwind of Africa, and never at station $\mathrm{M}$, which is less than $500 \mathrm{~km}$ from the continent. Radon- 222 activities above $7 \mathrm{pCi} \mathrm{m}^{-3}$ indicate a continental input to the air masses. Aerosol samples with 

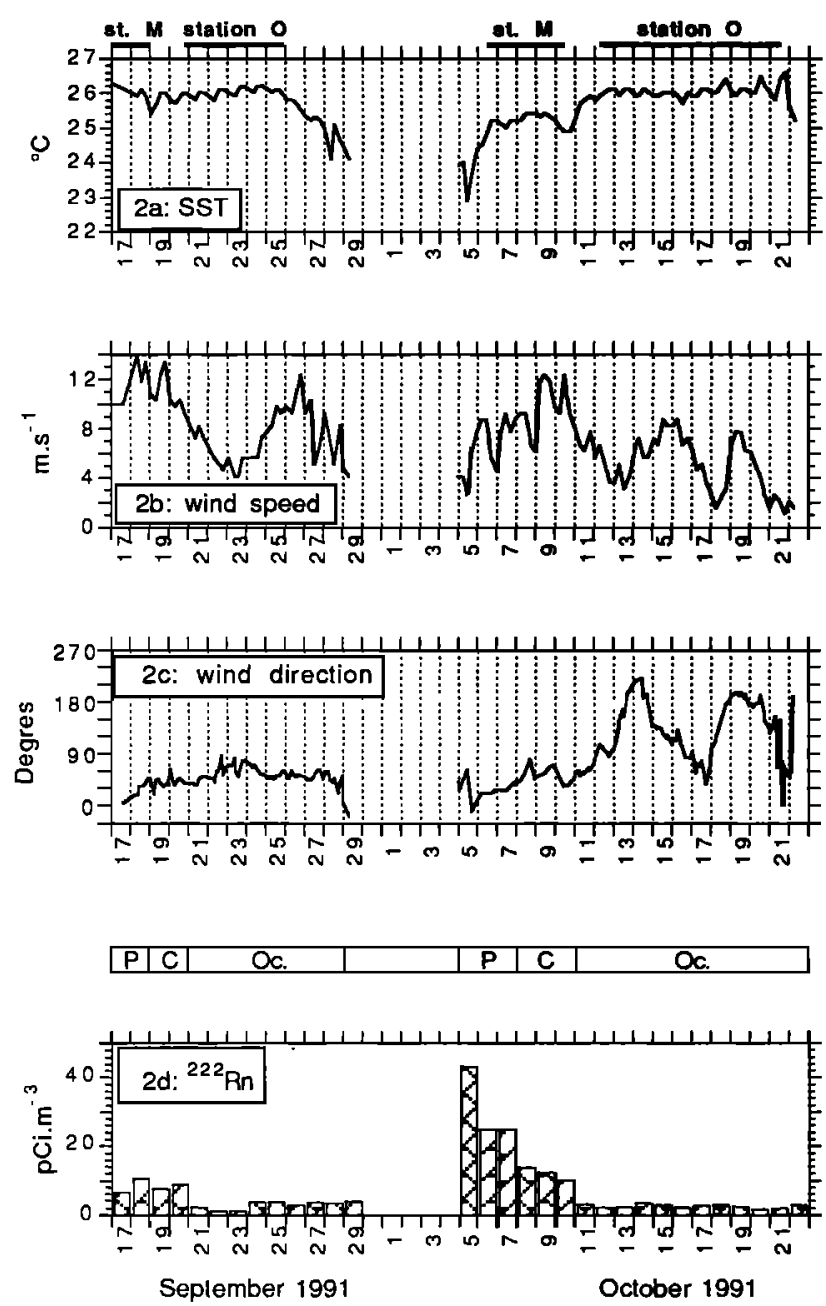

Fig. 2. Variations of $(a)$ surface seawater temperature, $(b)$ wind speed, $(c)$ wind direction, and $(d)$ daily mean ${ }^{222} \mathrm{Rn}$ activity. $\mathrm{P}$, $\mathrm{C}$ and Oc. indicate periods when polluted, continental and oceanic air masses occurred.

continental input generally presented high nss- $\mathrm{K}^{+}$and nss$\mathrm{Ca}^{2+}\left(1-8\right.$ and $3-24 \mathrm{nmol} \mathrm{m}^{-3}$, respectively), denoting advection of Saharan dust. This was particularly obvious on September 18 when the highest optical depth at $449 \mathrm{~nm}(1.55)$ was observed [F. Dulac, personal communication, 1992]. The $\mathrm{nss}-\mathrm{K}^{+} / \mathrm{nss}-\mathrm{Ca}^{2+}$ ratio observed on this day $(0.28)$ was close to the $\mathrm{nss}-\mathrm{K}^{+} / \mathrm{nss}^{-\mathrm{Ca}^{2}}{ }^{+}$ratio $(0.32)$ estimated from concentrations measured in air masses coming from Morocco [Bergametti et al., 1989], where anthropogenic sources of pollution are located. Anthropogenic inputs to the air mass sampled on this day were confirmed by the observation of a high $\mathrm{NO}_{3}^{-}$concentration $\left(>30 \mathrm{nmol} \mathrm{m}^{-3}\right.$ ). On September 19 20 , the ship was before the relative wind, so that aerosol sampling was stopped. We cannot therefore determine wether anthropogenic pollution occurred. During the period October $5-10$, nss- $\mathrm{K}^{+} / \mathrm{nss}-\mathrm{Ca}^{2+}$ was 0.19 on average, denoting advection of dust from the Sahelian areas, where anthropogenic pollution sources are scarce, and which are characterized by nss- $\mathrm{K}^{+} / \mathrm{nss}-\mathrm{Ca}^{2+}$ ratios of about 0.20 in aerosols [Bergametti et al., 1989]. However, $\mathrm{NO}_{3}{ }^{-}$ concentrations above $80 \mathrm{nmol} \mathrm{m} \mathrm{m}^{-3}$ were observed from October 5 to 7 , indicating a strong pollution of the sampled air mass by combustion and/or biomass burning processes. Finally, during the October 7.10 period there was no indication of any anthropogenic component in the air masses, so air masses can be considered to have passed over only unpolluted continental areas.

Air mass characteristics (polluted on September 17-18, continental from undetermined origin on September 19-20, oceanic on September 21-28, polluted on October 5-7, continental but unpolluted on October 8-10, and oceanic on October 11-21) are denoted by letters $P, C$, and Oc. in Figures 2,3 , and 4 .

\section{DMS Ocean-Atmosphere Flux}

Except during the period October 8-10, DMS concentrations in surface seawater ranged from 1.5 to 4.5 nmol $\mathrm{L}^{-1}$ without any marked latitudinal or longitudinal gradient (Figure $3 a$ ). These concentrations are close to those observed by Bürgermeister et al. [1990] and S. Belviso (unpublished data, 1992) in April 1987 and June 1992, respectively. During the second visit to station M (October 6$10)$, large increases in the subsurface (40-m depth) chlorophyll $a$ maximum $\left(0.4\right.$ to $\left.2.5-3.0 \mu \mathrm{g} \mathrm{L}^{-1}\right)$ and its surface concentration (0.2 to $\left.0.3-0.4 \mu \mathrm{g} \mathrm{L}^{-1}\right)$ ) was observed during the 7-10 October period (J. Neveux, personal communication, 1992). The SST observed on these days was significantly lower than that observed at the same point on September 17 18 (Figure $2 a$ ), suggesting an advection of coastal seawater from the African upwelling area. This event was associated with an increase in DMSP concentrations throughout the marine mixed layer and particularly at a 5-m depth where it increased from 22 to $45 \mathrm{nmol} \mathrm{L}^{-1}$ (S. Belviso, P. Buat-Ménard, J.P. Putaud, B.C. Nguyen, H. Claustre and J. Neveux, Size distribution of dimethylsulfoniopropionate in areas of the tropical northeastern Atlantic ocean and the Mediterranean sea, accepted in Marine Chemistry, 1993). This doubling in DMSP concentration was followed by an increase in the mean DMS concentration in surface seawater by a factor of $3.4(2.6$ on October 5-7 to $9.0 \mathrm{nmol} \mathrm{^{-1 }}$ on October 8-10). The latter value is consistent with DMS concentrations of about $10 \mathrm{nmol}$ $\mathrm{L}^{-1}$ observed at the edge of the upwelling area of Somali [Mihalopoulos et al., 1992].

Surface seawater has been reported to be supersaturated in DMS with respect to the atmosphere (see, for example, Bates et al., [1987a]), and although a large fraction of the dissolved DMS is recycled within the the water column, there is a positive DMS flux ( $F_{\text {DMS }}$ ) from the ocean to the atmosphere. $F_{\text {DMS }}$ can be estimated using a gas exchange model [Liss and Merlivat, 1986], and the relationship $F_{\mathrm{DMS}}=k_{w}[\mathrm{DMS}]_{\text {seawater }}$ where $k_{w}$ is the piston velocity depending on the local wind speed and SST [Liss and Merlivat, 1986]. During the EUMELI 3 cruise, large variations in wind speed resulted in $k_{w}$ values ranging from 0.1 to $25.0 \mathrm{~cm} \mathrm{~h}^{-1}$ (mean, 9.0; Figure $3 b$ ). Excluding the October 8-10 period, DMS sea-air flux was estimated to range between 0.1 and $14.6 \mu \mathrm{mol} \mathrm{m} \mathrm{m}^{-2}$ day $^{-1}$ (mean, 5.0; Figure $3 c$ ). This average is very close to the estimates made by Bates et al. [1987a] for the tropical north Pacific Ocean $\left(4.5 \mu \mathrm{mol} \mathrm{m}^{-2}\right.$ day $\left.^{-1}\right)$ and to the value calculated by Erickson et al. [1990] in their model for this area in July (exactly $5 \mu \mathrm{mol} \mathrm{m}^{-2} \mathrm{day}^{-1}$ ). However, during the October 8-10 period, when a combination of high wind speed and high DMS concentration in seawater occurred, the DMS flux increased to 14.3 - 58.2 $\mu \mathrm{mol} \mathrm{m}^{-2}$ day $^{-1}$ (mean, 30.8; Figure 3c). Taking into account these 3 days, a mean DMS sea-air flux of 7.9 $\mu \mathrm{mol} \mathrm{m}{ }^{-2}$ day $^{-1}$ is calculated for the whole period.

\section{Atmospheric Concentrations of DMS}

Atmospheric DMS concentrations ranged from $<0.8$ to 12.3 nmol $\mathrm{m}^{-3}$ (mean, 3.1, Figure $3 \mathrm{~d}$ ). This average is similar to the two values of $2-4 \mathrm{nmol} \mathrm{m}^{-3}$ measured in the same area by 



Fig. 3. Variations of (a) DMS concentration in surface seawater, $(b)$ estimated piston velocity, (c) calculated DMS sea-air flux, $(d)$ atmospheric DMS concentration, and $(e) \mathrm{CN}$ number concentration. $\mathrm{P}, \mathrm{C}$ and $\mathrm{Oc}$. indicate periods when polluted, continental and oceanic air masses occurred.

Bürgermeister and Georgii [1991] in April 1987. Although it is more relevant to compare an air mass with the water mass upwind of it, atmospheric concentrations and sea-air flux of DMS determined at the same points seemed to roughly covary during this experiment. Indeed, excluding the 3 days (October 8-10) when atmospheric DMS was unlikely to be in steady state because of the sharp increase in DMS flux, daily mean DMS flux and atmospheric concentrations were significantly correlated $(R=0.70, n=27, \mathrm{P}<0.001)$. It should be noted, however, that atmospheric DMS concentration depends not only on DMS flux, but also on its mixing throughout the atmospheric boundary layer and on oxidation rate in this layer. From the mean ratio between estimated DMS flux and measured atmospheric concentration $\left(0.6 \mathrm{~m}^{-1} \mathrm{~s}^{-1}\right)$, the atmospheric lifetime of DMS can be estimated to be 8-15 hours, assuming a 1 to 2-km-high boundary layer where atmospheric DMS would decrease to $\approx 0$ at its top, as described for airborne experiments [Luria et al., 1989; Berresheim et al., 1990]. This value is consistent with the estimate of 1 day by Bates et al. [1992b] over the equatorial Pacific Ocean, taking into account the probably high concentrations of oxidizing species owing to the almost continuous insolation during our experiment and to the advection of polluted air masses for 5 days (September 17-18 and October 5-7).

\section{Atmospheric Concentrations of $\mathrm{SO}_{2}$}

Over the 27 days when $\mathrm{SO}_{2}$ was sampled, its atmospheric concentrations ranged from $<0.15$ to $4.7 \mathrm{nmol} \mathrm{m}^{-3}$ (mean, 1.5; Figure $4 a$ ). These values are close to those of $0.5-3.9 \mathrm{nmol} \mathrm{m}^{-3}$ observed by Nguyen et al. [1983] in May 1974 in the same area and are consistent with the annual mean of $2 \mathrm{nmol} \mathrm{m}^{-3}$ calculated for this area by Langner and Rhode [1991] from their three-dimensional model.

Particularly high $\mathrm{SO}_{2}$ concentrations were observed on September 18 and 22 and October $5\left(4.6-4.7 \mathrm{nmol} \mathrm{m}^{-3}\right)$. These high values must be at least partially due to anthropogenic $\mathrm{SO}_{2}$ on September 18 and October 5 , since advection of polluted air masses was indicated on these days. For September 22, we have no indication of any transport of pollutants from continents $\left({ }^{222} \mathrm{Rn}\right.$ daily mean activity $=1.3$ pCi $\mathrm{m}^{-3}$ ). This high $\mathrm{SO}_{2}$ concentration could come from entrainment of $\mathrm{SO}_{2}$ from the free troposphere (FT), since Ockelman and Georgii [1989] measured six $\mathrm{SO}_{2}$ concentrations in the range $1.3-19.7 \mathrm{nmol} \mathrm{m}^{-3}$ (median, 5.3) in the FT over the west coast of Africa. However, the model of Langner and Rhode [1991] predicts $\mathrm{SO}_{2}$ annual mean concentrations of $1-2 \mathrm{nmol} \mathrm{m}^{-3}$ in the FT over the study area, which would not be sufficient to explain the $\mathrm{SO}_{2}$ concentration of $4.6 \mathrm{nmol} \mathrm{m}^{-3}$ observed on September 22 in the boundary layer. On that day, the ship often described circles to reach hydrographic stations. It is therefore possible that local pollution by the ship exhaust affected the $\mathrm{SO}_{2}$ concentration on those occasions.

If the data obtained on September 18 and 22 and October 5 are excluded, the daily average concentrations of $\mathrm{SO}_{2}$ and DMS (Figure $4 a$ and $4 b)$ are correlated $\left(\mathrm{SO}_{2}=0.3 \mathrm{DMS}+0.2 ; R=\right.$ $0.73, \mathrm{P}<0.001$ ), suggesting that the $\mathrm{SO}_{2}$ encountered in this area is mainly derived from DMS. The $\mathrm{SO}_{2} / \mathrm{DMS}$ ratio is very close to that observed by Bandy et al. [1992] during a 7-day experiment in the northeast Pacific Ocean (mean $\mathrm{SO}_{2}$ /mean DMS $=25 / 78$ ). Does this ratio mean that the yield of $\mathrm{SO}_{2}$ from DMS oxidation is low? It might indicate only that the atmospheric lifetime of $\mathrm{SO}_{2}$ is much shorter than that for DMS, because of the oxidation of $\mathrm{SO}_{2}$ by $\mathrm{OH} / \mathrm{O}_{2}$ which according to Atkinson et al. [1989], is almost as efficient as DMS oxidation by $\mathrm{OH}$ [Hynes et al., 1986; Hynes and Wine, 1989], and because of $\mathrm{SO}_{2}$ absorption in seawater and/or sea spray and subsequent heterogeneous oxidation, which are also important sinks for this compound [Lelieveld, 1990; Sievering et al., 1991; Putaud et al, 1992].

\section{Aerosol Ions}

We focused our attention on submicrometer aerosols and analyzed the 26 sampled final filters (stage 6) to get the concentrations of $\mathrm{Na}^{+}, \mathrm{K}^{+}, \mathrm{Ca}^{2+}, \mathrm{HCOO}^{-}, \mathrm{CH}_{3} \mathrm{COO}^{-}, \mathrm{MSA}$, $\mathrm{NO}_{3}{ }^{-}$, and $\mathrm{SO}_{4}{ }^{2-}$ in particles in the diameter range of $<0.6 \mu \mathrm{m}$. To estimate the size distributions of these compounds, 17 sixstage series were chosen to be homogeneously distributed during the experiment period and analysed for all these compounds except MSA, which was analyzed in only 9 of these six-stage series. 

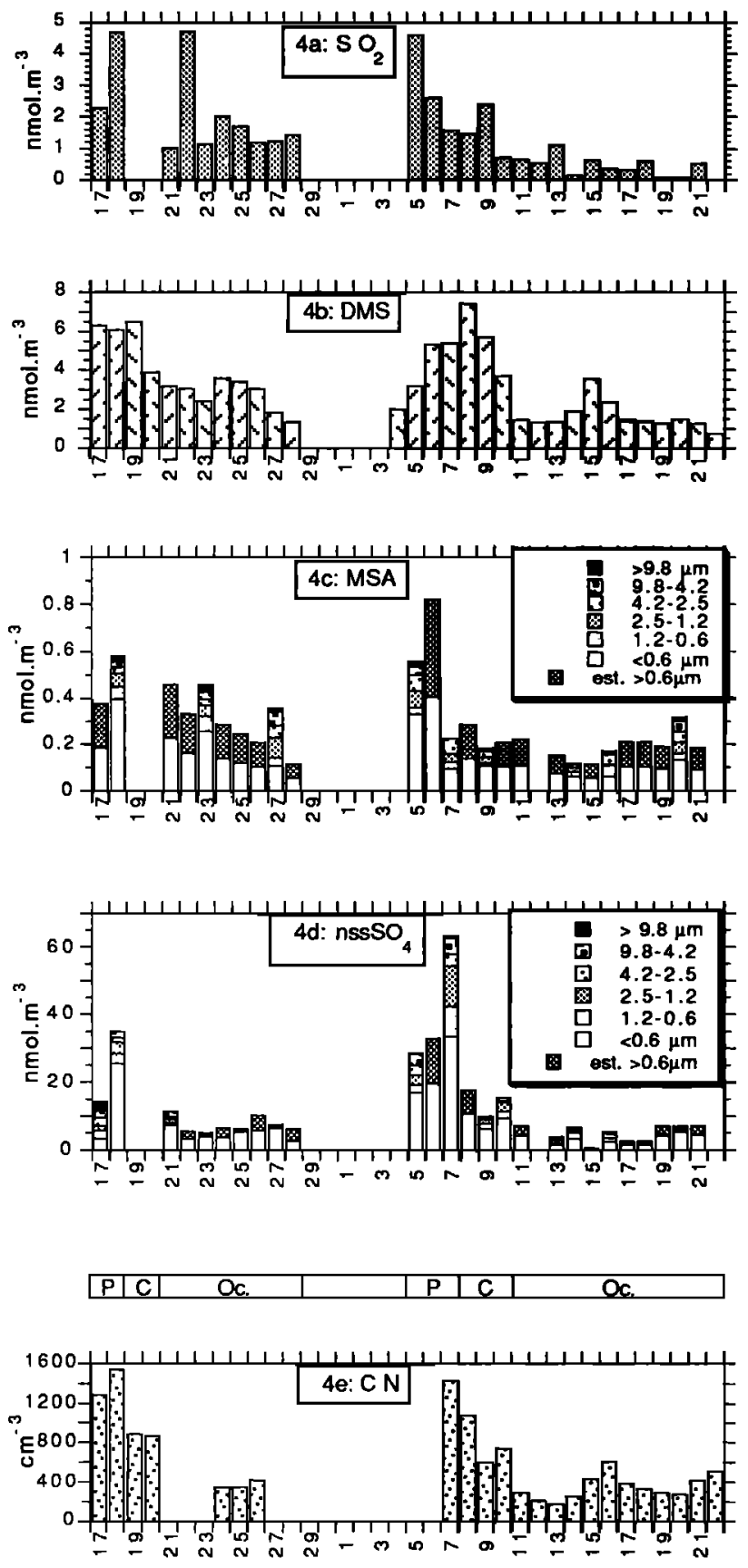

September 1991

October 1991

Fig. 4. Variations of (a) 24-hour integrated atmospheric $\mathrm{SO}_{2}$ concentration, (b) daily mean atmospheric DMS concentration, (c) $24 \mathrm{hr}$-intergrated particulate MSA concentration, (d) 24-hour intergrated particulate nss- $\mathrm{SO}_{4}{ }^{2-}$ concentration, and $(e)$ daily mean $\mathrm{CN}$ number concentration. No data were collected from September 29 to October 4, or on September 19-20 and October 22 for $\mathrm{SO}_{2}$, September 19-20 and October 12 and 22 for aerosols, or September 21-23, September 27-28, and October 5-6 for CN. P, C and Oc. indicate periods when polluted, continental and oceanic air masses occurred.

$\mathrm{Na}^{+}$concentrations ranged from 23 to $343 \mathrm{nmol} \mathrm{m}^{-3}$ (mean, 117; data not shown), which is consistent with values of 70 nmol $\mathrm{m}^{-3}$ obtained over the Atlantic Ocean from a ship [Bürgermeister and Georgii, 1991] and $130 \mathrm{nmol} \mathrm{m}^{-3}$ measured at Bermuda Island [Arimoto et al., 1992] during this season.
$\mathrm{Na}^{+}$was found to be predominantly in coarse particles and particularly in particles in the 4.2 to $9.8-\mu \mathrm{m}$-diameter range (45\%; Figure 5a). Long-range transport of such large particles is unlikely and the input of crustal sodium salts was probably a minor source of $\mathrm{Na}^{+}$with respect to sea spray in most cases. $\mathrm{Na}^{+}$will therefore be used as a sea-salt tracer to calculate nonsea-salt components in aerosols.

The results of organic acid measurements performed on the samples collected during EUMELI 3 are not presented here, since we suspect that the Accuvettes used to extract ionic compounds from the substrates and filters released some organic chemicals. In any case, carboxylic acid ( $\mathrm{HCOOH}+$ $\mathrm{CH}_{3} \mathrm{COOH}$ ) concentrations were generally less than $30 \%$ of nss $-\mathrm{SO}_{4}{ }^{2-}$ concentrations.

Because we washed the Whatman-41 paper filter and substrates in $0.1 \mathrm{M} \mathrm{HNO}_{3}$ solutions, the levels of $\mathrm{NO}_{3}^{-}$in our blanks were not zero (ranges, 13-46 and 21-104 $\mu \mathrm{g}$ /quarter of substrate and filter, respectively). For the minimum air volume sampled during the EUMELI 3 cruise, these values would have led to atmospheric concentrations of up to 4.7 and $10.6 \mathrm{nmol}$ $\mathrm{m}^{-3}$, respectively, which in some cases could be not negligible with respect to the concentrations measured during the cruise ( 6 to $112 \mathrm{nmol} \mathrm{m} \mathrm{m}^{-3}$; mean, $28.2 \mathrm{nmol} \mathrm{m}^{-3}$ ). Therefore, only days with measured $\mathrm{NO}_{3}{ }^{-}$concentrations above $30 \mathrm{nmol} \mathrm{m}^{-3}$ were considered in the discussion as being affected by advection of anthropogenic $\mathrm{NO}_{3}^{-}$, since these concentrations could hardly come from an artifact. The size distribution of $\mathrm{NO}_{3}^{-}$is well defined, with $58 \pm 20 \%$ being concentrated in particles in the diameter range 4.2-9.8 $\mu \mathrm{m}$ and almost $92 \%$ in particles larger than $2.5 \mu \mathrm{m}$ (Figure $5 b$ ). This clearly indicates that most gaseous $\mathrm{HNO}_{3}$ condenses on preexisting large particles close to $\mathrm{NO}_{\mathrm{x}}$ sources (for example in smoke plumes) and/or on sea-salt particles, which have a size distribution similar to that of $\mathrm{NO}_{3}{ }^{-}$(more than $86 \%$ in particles larger than $2.5 \mu \mathrm{m}$ ). $\mathrm{HNO}_{3}$ would therefore give fewer particles than other acidic species with comparable atmospheric concentrations, which would be concentrated in much smaller particles.

MSA analysis in 9 complete sets of six-stage impactor fractions indicated that $49 \pm 12 \%$ of the collected MSA was in the final filter, i.e. in particles with diameters of $<0.6 \mu \mathrm{m}$ (Figure $5 c$ ). The standard deviation for this average being quite small, this percentage was used to estimate the total MSA concentrations from the value measured in the remaining 17 daily final filters. MSA total concentrations ranged from 0.1 to $0.8 \mathrm{nmol} \mathrm{m}^{-3}$ (Figure $4 c$ ), and the average $\left(0.3 \mathrm{nmol} \mathrm{m}^{-3}\right)$ was very close to the values observed by Bürgermeister and Georgii [1991] $\left(0.23-0.25 \mathrm{nmol} \mathrm{m}^{-3}\right)$ during their two visits to this area. MSA seems to roughly covary with DMS during the first leg, whereas during the second leg no relationship appears between MSA and DMS daily mean concentrations (Figure $4 b$ and $4 c$ ) either for estimated total concentrations or for concentrations measured in the submicrometer aerosol fraction. This lack could be due to several factors. First, the MSA/DMS ratio is related to the kinetics and branching ratio of DMS oxidation. This ratio is thought to depend on oxidizing species concentrations (for example, $\mathrm{OH}$ and $\mathrm{NO}_{3}$ ) which could have been higher in polluted air masses on October 5-6. Second, the DMS lifetime is known to be shorter than the aerosol lifetime. MSA concentration should also reflect the DMS concentration observed in the same air mass a few days earlier. The high MSA concentrations observed on October 5-6 could therefore also be partially caused by a strong DMS emission from the edge of the upwelling area at the west coast of North Africa. In the same way, if the increase in DMS production on October 8-10 was a local phenomenon, this would explain the low MSA/DMS ratio observed on these days when the wind speed $\left(9-11 \mathrm{~m} \mathrm{~s}^{-1}\right)$ allowed DMS to be 



Fig. 5. Mean size distributions of $(a) \mathrm{Na}^{+}(\mathrm{n}=17),(b) \mathrm{NO}_{3}^{-}(n=$ 17), (c) MSA $(n=9)$, and (d) $\mathrm{nssSO}_{4}{ }^{2-}(n=17)$. The line inside each small box indicates the median value of the variable, and the top and bottom of each small box mark the limits of $\pm 25 \%$ of the variable. Error bars indicate standard deviations. Open circles are values out of the range of means \pm standard deviations. transported downwind quickly enough that an increase in the local MSA concentration could not be observed. Finally, MSA is a minor product of DMS oxidation (see the following paragraph), so that small variations in MSA concentration lead to a great change in the MSA/DMS ratio.

The nss-sulfate concentrations were calculated from the total sulfate and $\mathrm{Na}^{+}$concentrations in all the final filters and in 17 complete sets of six-stage impactor fractions (the molar ratio of $\mathrm{SO}_{4}{ }^{2-} / \mathrm{Na}^{+}$in seawater $=0.06$ ). We found that on average, nss- $\mathrm{SO}_{4}{ }^{2-}$ represented $62 \%$ of the total $\mathrm{SO}_{4}{ }^{2-}$ and that $60 \pm 18 \%$ of this nss- $\mathrm{SO}_{4}{ }^{2-}$ was in the finest particles (diameter of $<0.6 \mu \mathrm{m}$; Figure $5 d$ ). This large fraction of nss$\mathrm{SO}_{4}{ }^{2-}$ in the submicrometer particles suggests that particulate$\mathrm{H}_{2} \mathrm{SO}_{4}$ production does not predominantly occur on preexisting large particles like sea-salts, $86 \%$ of which have diameters greater than $2.5 \mu \mathrm{m}$ (Figure $5 a$ ). It also confirms that $\mathrm{H}_{2} \mathrm{SO}_{4}$ can form numerous submicrometer particles that can be important $\mathrm{CN}$ precursors over this oceanic area downwind of a continent. The total nss- $\mathrm{SO}_{4}{ }^{2-}$ concentration was estimated for the 10 days for which $\mathrm{SO}_{4}{ }^{2-}$ was not measured in stages $1-5$ by using the nss- $\mathrm{SO}_{4}{ }^{2-}$ concentration measured in each fraction of $<0.6-\mu \mathrm{m}$-diameter particles and the $60 \%$ ratio (mean nss- $\mathrm{SO}_{4}{ }^{2-}$ in fraction of $<0.6-\mu \mathrm{m}$-diameter particles/total $\mathrm{nss}-\mathrm{SO}_{4}{ }^{2-}$ ). Total nss- $-\mathrm{SO}_{4}{ }^{2-}$ concentration was found to range from 1 to 64 nmol $\mathrm{m}^{-3}$ (mean, 14.2; Figure $4 d$ ). This mean value is consistent with the concentration (about $20 \mathrm{nmol} \mathrm{m}^{-3}$ ) measured in the same area by Bürgermeister and Georgii [1991] in September and October 1988. The mean MSA/nss-SO 4 ratio was $3.5 \%$ during the experiment, which is exactly the same value as that observed by Bates et al. [1992b] at $20^{\circ} \mathrm{N}$ in the Pacific Ocean and is between the values of 1.5 and $6.5 \%$ observed at $20^{\circ} \mathrm{N}, 30^{\circ} \mathrm{W}$ by Bürgermeister and Georgii [1991] and at American Samoa (14 $\left.{ }^{\circ} \mathrm{S}\right)$ by Saltzman et al. [1986]. No good correlation was observed between nss- $\mathrm{SO}_{4}{ }^{2-}$ and DMS concentrations from the entire data set and particularly for the second leg in polluted air masses. It should be noted that on October 7 , the high nss-Ca ${ }^{2+}$ loading $\left(>10 \mathrm{nmol} \mathrm{m}^{-3}\right)$, with almost $80 \%$ concentrated in the 4.2 to $9.8-\mu \mathrm{m}$-diameter range, indicates an additional source of crustal nss- $\mathrm{SO}_{4}{ }^{2-}$ aerosol on this day, since gypsum $\left(\mathrm{CaSO}_{4} \cdot 2 \mathrm{H}_{2} \mathrm{O}\right)$ is known to be a component of desert aerosol. Excluding the values obtained in polluted air masses, nss- $\mathrm{SO}_{4}{ }^{2-}$ concentrations correlated with DMS atmospheric concentrations $(R=0.66, n=21, \mathrm{P}<$ 0.001 ). However, even during the period October $11-21$, the feature observed in DMS atmospheric concentration (particularly its increase on October 15) was not reflected in nss- $\mathrm{SO}_{4}{ }^{2-}$ concentrations (Figure $4 b$ and $4 d$ ), indicating that because of its several-hour lifetime, DMS is not immediately oxidized in a mass of nss- $\mathrm{SO}_{4}{ }^{2-}$ large enough to be detected against the $\mathrm{SO}_{4}{ }^{2-}$ background.

\section{Condensation Nuclei}

Over 402 hours of measurements, the $\mathrm{CN}$ number concentration ranged from 155 to $1890 \mathrm{~cm}^{-3}$ (mean, 586; Figure $3 e$ ). This mean value is above those found by Bates $e t$ al. [1987b] at $14^{\circ} \mathrm{S}$ and $41^{\circ} \mathrm{S}$ in the Pacific Ocean (about 380 $\mathrm{cm}^{-3}$ ), but the mean is influenced by some large values obtained under continental influence. Indeed, in oceanic air masses we calculated a mean $\mathrm{CN}$ number concentration of 354 $\pm 108 \mathrm{~cm}^{-3}$, which is close to the oceanic background. When the daily mean $\mathrm{CN}$ concentrations (Figure $4 e$ ) are compared with all the 24-hr integrated aerosol concentrations, the best correlation is found with the finest fraction $(<0.6-\mu \mathrm{m}-$ diameter) of nss-SO ${ }_{4}^{2-}(R=0.91, n=17, \mathrm{P}<0.001$; Figure 6$)$. This indicates that the finest fraction of nss- $\mathrm{SO}_{4}{ }^{2-}$, which represents $60 \%$ of its mass and therefore a very large majority 


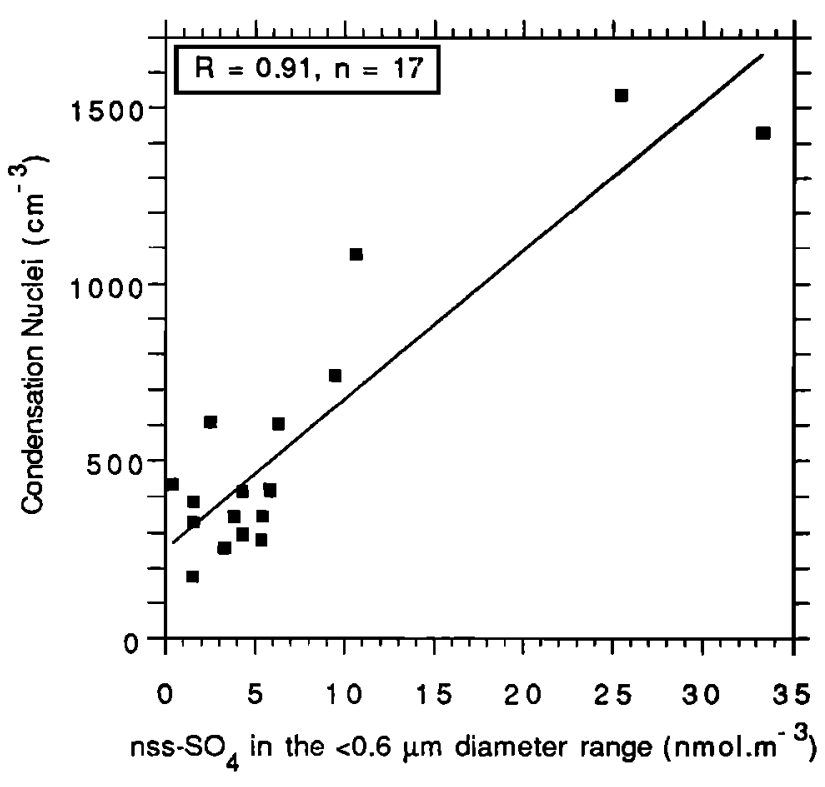

Fig. 6. Relationship between daily mean $\mathrm{CN}$ number concentration and $24-\mathrm{hr}$ integrated concentration of particulate nss- $\mathrm{SO}_{4}{ }^{2-}$ in the $<0.6-\mu \mathrm{m}$-diameter range.

of nss- $\mathrm{SO}_{4}{ }^{2-}$ particles, contributes significantly to the $\mathrm{CN}$ population over this oceanic area. The nss- $\mathrm{SO}_{4}{ }^{2-}$ is thought to be primarily $\mathrm{H}_{2} \mathrm{SO}_{4}$, which is only partially neutralized mainly by $\mathrm{NH}_{3}$ in the submicrometer particles, whereas sea spray sulfates are neutral salts (e.g. $\mathrm{Na}_{2} \mathrm{SO}_{4}, \mathrm{~K}_{2} \mathrm{SO}_{4}, \mathrm{MgSO}_{4}$, and $\mathrm{CaSO}_{4}$ ). Therefore, the fact that $\mathrm{nss}-\mathrm{SO}_{4}{ }^{2-}$ is better correlated with $\mathrm{CN}$ than total $\mathrm{SO}_{4}{ }^{2-}$ suggests the importance of $\mathrm{H}_{2} \mathrm{SO}_{4}$ in the production of particles larger than the minimum detection limit of a $\mathrm{CN}$ counter ( $100 \%$ efficiency for diameter of $0.02 \mu \mathrm{m}$ decreasing to 0 for diameter of $0.005 \mu \mathrm{m}$ ). Aqueous phase oxidation of $\mathrm{SO}_{2}$ in droplets and condensation of gaseous $\mathrm{H}_{2} \mathrm{SO}_{4}$ on prexisting freshly nucleated particles (radius $\approx 0.001 \mu \mathrm{m}$ ) could be two of the processes producing condensed $\mathrm{H}_{2} \mathrm{SO}_{4}$, the latter being efficient enough to give detectable $\mathrm{CN}$ in a reasonnable time according to models recently described [Raes and Van Dingenen, 1992; Lin et al., 1992].

It should be noted that the two points with the highest $\mathrm{CN}$ concentrations (related to the data obtained on September 18 and October 7), which have a large weight in the correlation between DMS and nss-SO ${ }_{4}^{2-}$, correspond to air masses influenced by anthropogenic sources. This, together with the ratio between the mean $\mathrm{CN}$ number concentrations obtained under continental and oceanic influence (1055/354), indicates that the $\mathrm{CN}$ population can be strongly affected by continental inputs over the oceanic area situated around site $M$. Therefore, the correlation observed between atmospheric DMS and the $\mathrm{CN}$ number concentration ( $R=0.82, n=21$; Figure 7) must be carefully considered, since the highest DMS concentrations were always observed close to station $M$ with strong northeastern winds and therefore with advection of air masses affected by continental inputs. The atmospheric circulation patterns encountered during EUMELI 3 cruise therefore generally preclude determining any connection between DMS and $\mathrm{CN}$ over the study area.

However, indications of continental influences were never detected at station $\mathrm{O}$, and in oceanic conditions the increase of the DMS flux observed from October 12 to $15(2.4$ to $8.1 \mu \mathrm{mol}$ $\mathrm{m}^{-2}$ day $^{-1}$; Figure $3 c$ ) and associated with an increase in the daily mean atmospheric DMS concentration (from 1.3 to 3.6 $\mathrm{nmol} \mathrm{\textrm {m } ^ { - 3 }}$; Figure $4 b$ ) was followed by an increase in the daily

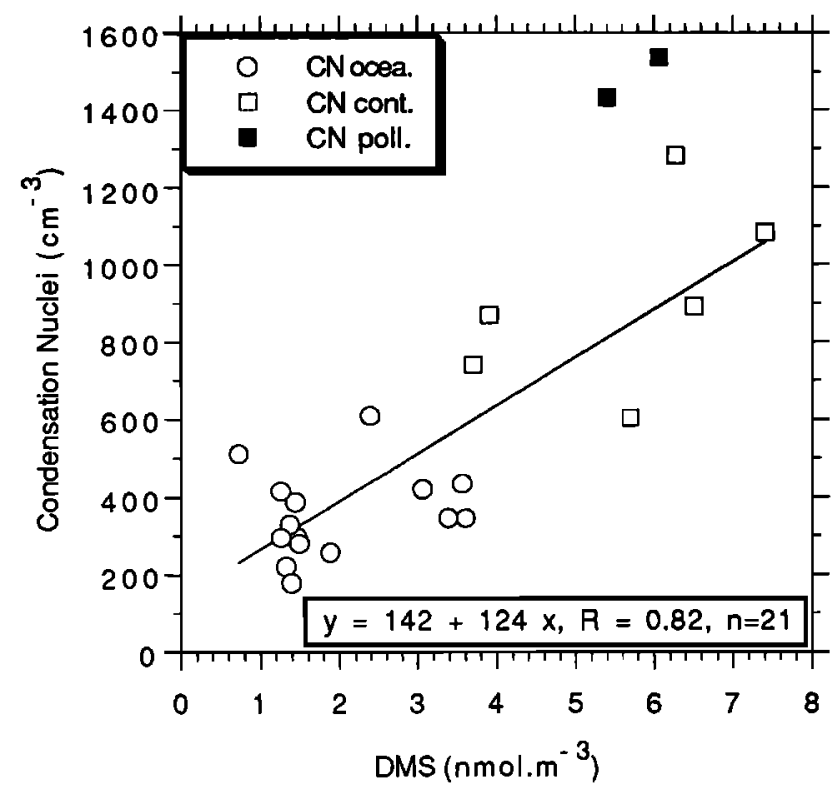

Fig. 7. Relationship between atmospheric DMS and $\mathrm{CN}$ number daily mean concentrations. Solid squares, open squares, and open circles correspond to polluted, continental, and oceanic air masses, respectively.

mean $\mathrm{CN}$ number concentration (220 to $434 \mathrm{~cm}^{-3}$ on October 15 and $609 \mathrm{~cm}^{-3}$ on October 16; Figure 4e). During this period, no variation in continental tracer was observed and the doubling in $\mathrm{Na}^{+}$concentration (from 40 to $80 \mathrm{nmol} \mathrm{m}^{-3}$ ) due to the increase in wind speed, was unable to play an important role in the $\mathrm{CN}$ number concentration because of $\mathrm{Na}^{+}$size distribution (more than $75 \%$ in the diameter range of $>4.2 \mu \mathrm{m}$ on October 16). CN population could have been affected by other compounds, whose variations would be similar to those of DMS, and which would oxidize in the atmosphere to acidic compounds able to contribute to the production of $\mathrm{CN}$. Reactive organic compounds emitted from the ocean (such as $\mathrm{C}_{2} \mathrm{H}_{4}$ ) could have been good candidates since carboxylic acids ( $\mathrm{HCOOH}$ and $\mathrm{CH}_{3} \mathrm{COOH}$ ) have been estimated to contribute the same fraction as nss- $\mathrm{SO}_{4}{ }^{2-}(25 \%)$ to the acidity of rainwater samples collected at Amsterdam Island [Moody et al., 1991]. However, the $\mathrm{HCOOH}+\mathrm{CH}_{3} \mathrm{COOH}$ concentration in the finest aerosol fraction $(<0.6-\mu \mathrm{m}$-diameter) on October 16 was $<0.5$ $\mathrm{nmol} \mathrm{m}{ }^{-3}$, whereas the nss-SO ${ }_{4}{ }^{2-}$ concentration was $2.5 \mathrm{nmol}$ $\mathrm{m}^{-3}$ in the same fraction. A strong influence by organic acids therefore being excluded, our observations indicate that DMS flux and/or atmospheric concentration directly influenced the $\mathrm{CN}$ number concentration over the ocean despite the vicinity of a continent (less than $1500 \mathrm{~km}$ upwind). It should be noted that this increase in $\mathrm{CN}$ number concentration was not associated with an increase in $\mathrm{MSA}$ or $\mathrm{nss}-\mathrm{SO}_{4}$ mass concentration. This finding could indicate that the $\mathrm{CN}$ formed from DMS oxidation products are smaller. Indeed, an increase in the population of particles in a diameter range of $0.02-0.2$ $\mu \mathrm{m}$ would have been detected with $100 \%$ efficiency by our particle counter, whereas it would have had a negligible effect $(<5 \%)$ on the mass concentration of a background aerosol (even in the $<0.6-\mu \mathrm{m}$-diameter stage) which would have presented a mean diameter 3 times larger.

\section{CONClusion}

During the oceanographic cruise EUMELI 3, the DMS concentration in the surface seawater did not present any marked spatial gradient, but the presence at station $M$ of 
advected seawater from the edge of the upwelling led to a large increase in the DMSP concentration through the marine mixed layer. This was followed by an increase in the DMS concentration in seawater by a factor of 3.4 , which contributed to a sharp enhancement of DMS flux. Generally, the daily mean atmospheric DMS concentration covaried with the daily mean DMS sea-air flux. For several reasons, including continental inputs of $\mathrm{SO}_{2}, \mathrm{nss}-\mathrm{SO}_{4}$, and/or oxidizing species changing the DMS lifetime, and differences between reactive gases and aerosol lifetimes, no obvious covariation between DMS and its oxidation products $\left(\mathrm{SO}_{2}, \mathrm{H}_{2} \mathrm{SO}_{4}, \mathrm{MSA}\right)$ appeared during the whole period of the experiment. However, the selection of data by using some atmospheric tracer levels ${ }^{222} \mathrm{Rn}$ activity and $\mathrm{NO}_{3}{ }^{-}$concentration in aerosols) allowed us to demonstrate that the $\mathrm{SO}_{2}$ and nss- $\mathrm{SO}_{4}$ concentrations could be related to that of DMS in unpolluted air masses. The ratio between the two main oxidation final products of DMS was $\mathrm{MSA} / \mathrm{H}_{2} \mathrm{SO}_{4}=3.5 \%$. These two products were found to be predominantly concentrated in the finest fraction of aerosols (diameter of $<0.6 \mu \mathrm{m}$ ), which indicates that they form numerous little particles. The correlation between nss-SO ${ }_{4}^{2-}$ concentration in the finest aerosol fraction $(<0.6-\mu$ m-diameter particles) and daily mean $\mathrm{CN}$ number concentration suggests the influence of $\mathrm{H}_{2} \mathrm{SO}_{4}$ on the $\mathrm{CN}$ population. $\mathrm{CN}$ number concentration was 3 times higher in continental air masses than in maritime ones. Consequently, the connection between DMS and $\mathrm{CN}$ cannot be inferred from the correlation between their daily mean values $(R=0.82, n=21, \mathrm{P}<0.001)$, since ${ }^{222} \mathrm{Rn}$ monitoring indicated possible continental influences during the period when the highest $\mathrm{CN}$ and DMS atmospheric concentrations were simultaneously observed. However, over $1500 \mathrm{~km}$ away from the African continent and under oceanic influence, when the DMS flux tripled, the atmospheric DMS concentration tripled, as did the $\mathrm{CN}$ concentration number. This shows that DMS can in some cases influence the $\mathrm{CN}$ population over the oceans even in areas relatively close to a continent.

Acknowledgments. We thank J. Neveux for providing chlorophyll data, F. Dulac for providing optical depth measurements, and the officers and crew of the IFREMER ship L'Atalente for their assistance and cooperation. E.C. Kent and two anonymous reviewers are particulary acknowledged for their helpful comments on the original manuscript. This work was supported by the Centre National de la Recherche Scientifique, the Commissariat l'Energie Atomique, and the Ministere de la Recherche et de la Technologie. This is CFR Contribution 1361.

\section{REFERENCES}

Andreae, M. O., The ocean as a source of atmospheric sulfur compounds, in The Role of Air-Sea Exchange in Geochemical Cycling, edited by P. Buat-Ménard, pp. 331362, D. Reidel, Norwell, Mass., 1986.

Arimoto R., R. A. Duce, D. L. Savoie, and J. M. Prospero, Trace elements in aerosol particles from Bermuda and Barbados: Concentrations, source and relationship to aerosol sulfate, J. Aimos. Chem., 14, 439-457, 1992.

Atkinson, R., D. L. Baulch, R. A. Cox, R. F. Hampson Jr., J. A. Kerr, and J. Troe, Evaluated kinetic and photochemical data for atmospheric chemistry: Supplement III, J. Phys. Chem. Data, 18, 881-1097, 1989.

Ayers, G. P., J. P. Ivey, and R. W. Gillett, Coherence between seasonal cycles of dimethyl sulphide, methanesulphonate and sulphate in marine air, Nature, 349, 404-406, 1991.

Bandy, A. R., D. L. Scott, B. W. Blomquist, S. M. Chen, and D. C. Thomton, Low yields of $\mathrm{SO}_{2}$ from dimethylsulfide oxidation in the marine boundary layer, Geophys. Res.
Lett., 19, 1125-1127, 1992.

Barnes, I., B. Bonsang, T. Brauers, P. Carlier, R. A. Cox, H. P. Dorn, M. E. Jenkin; G. Le Bras, and U. Platt, Laboratory and field studies of oxidation processes occurring in the atmospheric marine boundary layer, edited by G. Le Bras, Air Pollut. Res. Rep. 35, Environ. Res. Programme, Comm. Europ. Commun., 1991.

Bates, T. M., J. D. Cline, R. H. Gammon, and S. R. KellyHansen, Regional and seasonal variation of the flux of oceanic dimethylsulfide to the atmosphere, J. Geophys. Res., 92, 2930-2938, 1987a.

Bates, T. S., R. J. Charlson, and R. H. Gammon, Evidence for the climatic role of marine biogenic sulphur, Nature, 329 , 319-321,1987b.

Bates, T. S., B. K. Lamb, A. B. Guenther, J. Dignon, and E. S. Stoiber, Sulfur emissions to the atmosphere from natural sources, J. Atmos. Chem., I4, 315-337, 1992a.

Bates, T. S., J. A. Calhoun, and P. K. Quinn, Variations in the methanesulfonate to sulfate molar ratio in submicrometer particles over the south pacific ocean, J. Geophys. Res, 97, 9859-9865, 1992b.

Belviso, S., S. K. Kim, F. Rassoulzadegan, B. Krajka, B. C. Nguyen, N. Mihalopoulos, and P. Buat-Ménard, Production of dimethylsulfoniopropionate (DMSP) and dimethylsulfide (DMS) by the microbial food web, Limnol. Oceanogr., 35, 1810-1821, 1990.

Bergametti, G., L. Gomes, G. Coudé-Gaussen, P. Rognon, and M. N. Le Costumier, African dust observed over Canary Islands: Source-regions identification and transport pattern for some summer situations, J. Geophys. Res., 94, 14855 14864, 1989.

Berresheim, H., M. O. Andreae, G. P. Ayers, R. W. Gillett, J. T. Merrill, V. J. Davis, and W. L. Chameides, Airborne measurements of dimethylsulfide, sulfur dioxide, and aerosol ions over the Southern ocean south of Australia, $J$. Atmos. Chem., 10, 341-370, 1990.

Bürgermeister, S., and H. W. Georgii, Distribution of methane sulfonate, nss-sulfate and dimethylsulfide over the Atlantic and the North Sea, Atmos. Environ., 25A, 587-595, 1991.

Bürgermeister, S., R. L. Zimmerman, H. W. Georgii, H. G. Bingemer, G. O. Kirst, M. Jansen, and W. Emst, On the biogenic origin of dimethylsulfide: Relation between chlorophyll, ATP, organismic DMSP, phytoplankton species, and DMS distribution in Atlantic surface seawater and atmosphere, J. Geophys. Res., 95, 20607-20615, 1990.

Charlson R. J., D. S. Covert, T. V. Larson, and A. P. Waggoner, Chemical properties of tropospheric sulfur aerosol, Atmos. Environ., 12, 39-53, 1978.

Charlson R. J., J. E. Lovelock, M. O. Andreae, and S.G. Warren, Oceanic phytoplankton, atmospheric sulphur, cloud albedo and climate, Nature, 326, 655-661, 1987.

Charlson R.J., J. Langner, and H. Rhode, Sulfate aerosol and climate, Nature, 348, 22, 1990.

Charlson R. J., S. E. Schwartz, J. M. Hales, R. D. Cess, J. A. Coakley Jr, J. E. Hansen, and D. J. Hoffman, Climate forcing by anthropogenic aerosols, Science, 255, 423$430,1992$.

Cline, J. D., and T. S. Bates, Dimethylsulfide in the equatorial pacific Ocean: A natural source of sulfur to the atmosphere, Geophys. Res. Lett., 10, 949-952, 1983.

Coakley, J. A., Jr, R. L. Bernstein, and P. A. Durkee, Effects of ship-stack effluents on cloud reflectivities, Science, $237,1020-1022,1987$.

Dacey, J. W. H., and S. G. Wakeham, Oceanic dimethylsulfide: production during zooplankton grazing on phytoplankton, Science, 233, 1314-1316, 1986.

Erickson, D. J., III, S. J. Ghan, and J.E. Penner, Global oceanto-atmosphere dimethyl sulfide flux, J. Geophys. Res., 95, 
7546-7552, 1990

Gras, J. L., Cloud condensation nuclei over the southem ocean, Geophys. Res. Lett., 17, 1565-1567, 1990.

Hegg, D. A., R. J. Ferek, P. V. Hobbs, and L.F. Radke, Dimethyl sulfide and cloud condensation nucleus correlations in the northeast Pacific Ocean, J. Geophys. Res., 96, 13,189-13,191, 1991.

Hynes, A. J., and P. H. Wine, OH-initiated oxidation of biogenic sulfur compounds, in Biogenic Sulfur in the Environment, Am. Chem. Soc. Symp. Ser. 393, edited by E. S. Saltzman and W. J. Cooper, pp. 424-436, Washington D.C., 1989.

Hynes, A. J., P. H. Wine, and D. H. Semmes, Kinetics and mechanisms of $\mathrm{OH}$ reactions with organic sulfides, $J$. Phys. Chem., 90, 4148-4156, 1986.

Keller, M. D., W. K. Bellows, and R. R. L. Guillard, Dimethylsulfide production in marine phytoplankton, in Biogenic Sulfur in the Environment, Am. Chem. Soc. Symp. Ser. 393, edited by E. S. Saltzman and W. J. Cooper, pp. 167-182, Washington D.C., 1989.

Kiene, R. P., and T. S. Bates, Biological removal of dimethylsulfide from seawater, Nature, 345, 6277-6279, 1990.

Langner, J., and H. Rhode, A global three-dimensional model of the tropospheric sulfur cycle, J. Atmos. Chem., 13, 225263, 1991.

Legrand, M. R., R. J. Delmas, and R.J. Charlson, Climate forcing implication from Vostok ice-core sulphate data, Nature, 334, 418-420, 1988.

Leiatch, W. R., G. A. Isaac, J. W. Strapp, C. M. Banic, and H.A. Wiebe, The relationship between cloud droplet number concentrations and anthropogenic pollution: Observations and climatic implications, J. Geophys. Res., 97, 2453-2474, 1992.

Lelieveld, J., The role of clouds in tropospheric photochemistry, Ph. D. thesis, Univ. of Utrecht, Utrecht, Netherlands, 1990.

Lin, X., W. L. Chameides, C. S. Kiang, A. W. Stelon, and H. Berresheim, A model study of the formation of cloud condensation nuclei in remote marine areas, $J$. Geophys. Res., 92, 18161- 18171, 1991.

Liss, P. S., and L. Merlivat, Air-sea gas exchange rates: Introduction and synthesis, in The Role of Air-Sea Exchange in Geochemical Cycling, edited by P. BuatMénard, pp. 113-128, D. Reidel, Horwell, Mass., 1986.

Luria, M., C. C. Van Valin, J. N. Galloway, W. C. Keene, D. L. Wellman, H. Sievering, and J. F. Boatman, The relationship between dimethylsufide and particulate sulfate in the mid-Atlantic ocean atmosphere, Atmos. Environ., 23, 139-147, 1989.

Mihalopoulos, N., B. C. Nguyen, J. P. Putaud, and S. Belviso, The oceanic source of carbonyl sulfide (COS), Atmos. Envir, 26A, 1383-1394, 1992.

Moody, J. L., A. A. P. Pszenny, A. Gaudry, W. C. Keene, J. N. Galloway, and G. Polian, Precipitation composition and its variability in the Southern Indian Ocean: Amsterdam lsland, 1980-1987, J. Geophys. Res., 96, 20769-20786, 1991.

Nguyen, B. C., B. Bonsang, and G. Lambert, The atmospheric concentration of sulfur dioxide and sulfate aerosol over antarctic, subantarctic areas and ocean, Tellus, 26, 241247, 1974.

Nguyen B. C., B. Bonsang, and A. Gaudry, The role of the ocean in the global atmospheric sulfur cycle. J. Geophys.
Res., 88, 10903-10914, 1983.

Nguyen, B. C., S. Belviso, N. Mihalopoulos, J. Gostan, and P. Nival, Dimethylsulfide production during natural phytoplanktonic blooms, Marine Chem., 24, 133-141, 1988 .

Nguyen, B. C., N. Mihalopoulos, and S. Belviso, Seasonal variation of atmospheric dimethyl sulfide at Amsterdam Island in the southern Indian Ocean, J. Atmos. Chem., 11, 123-143, 1990.

Nguyen, B. C., N. Mihalopoulos, J. P. Putaud, A. Gaudry, L. Gallet, W. C. Keene, and J. N. Galloway, Covariations in oceanic dimethylsulfide, its oxidation products and rain acidity at Amsterdam Island in the southern Indian Ocean, J. Atmos. Chem., 15, 39-53, 1992.

Ockelman, G. E. F., and H. W. Georgii, Grossräumige Verteilung des atmosphärischen Schwefeldioxids in der freien Troposphäre, Meteorol. Rundsch., 41, 136-146, 1989.

Polian, G., G. Lambert, B. Ardouin, and A. Jégou, Long range transport of continental radon in subantarctic areas, Tellus, $38 B, 178-189,1986$.

Putaud, J. P., N. Mihalopoulos, B. C. Nguyen, J. M. Campin, and S. Belviso, Seasonal variations of atmospheric sulfur dioxide and dimethylsulfide concentrations at Amsterdam Island in the southern Indian Ocean, J. Atmos. Chem., 15, 117-131, 1992.

Radke, L. F., J. A. Coakley, Jr., and M. D. King, Direct and remote sensing observation of the effect of ships on clouds, Science, 246, 1146-1149, 1989.

Raes, F., and R. Van Dingenen, Simulations of condensation and cloud condensation nuclei from biogenic $\mathrm{SO}_{2}$ in the remote marine boundary layer, J. Geophys. Res., 97, 12901-12912, 1992.

Saltzman, E. S., D. L. Savoie, J. M. Prospero, and R. G. Zika, Methane sulfonic acid and non-sea-salt sulfate in Pacific air: Regional and seasonal variations, J. Atmos. Chem., 4, 227-240, 1986.

Sievering, H., J. F. Boatman, J. N. Galloway, W. C. Keene, Y. Kim, M. Luria, and J. Ray, Heterogeneous sulfur conversion in sea-salt aerosol particles: The role of aerosol water content and size distribution, Atmos. Environ., 25A, 1479-1487, 1991.

Twomey, S., The composition of cloud nuclei, J. Atmos. Sci., 28, 377-381, 1971.

Watts, S. F., R. Yaaqub, and T. Davies, Comments on "The use of Whatman 41 filter papers for high volume aerosol sampling" by Lodge, [1986], Atmos. Environ., 21, 27312732, 1987.

Wigley, T. M. L., Possible climatic change due to $\mathrm{SO}_{2}$-derived cloud condensation nuclei, Nature, 339, 365-367, 1989.

Yin F., D. Grosjean, and J. H. Seinfeld, Photooxidation of dimethylsulfide and dimethyldisulfide, I, Mechanism development, J. Atmos. Chem., 11, 309-344, 1990.

S. Belviso, N. Mihalopoulos, B.C. Nguyen, and J.P. Putaud, Centre des Faibles Radioactivités, Laboratoire mixte CNRSCEA, Ave. de la Terrasse, F-91198 Gif-sur-Yvette Cedex, France.

(Received December 1, 1992; revised March 18, 1993; accepted March 23, 1993) 